\title{
A multiplex PCR assay for rapid identification of major tospovirus vectors reported in India
}

\author{
Sumit Jangra, Anubha Mittal, Heena Dhall, Rakesh Kumar Jain and Amalendu Ghosh ${ }^{*}$ (D)
}

\begin{abstract}
Background: To date, four thrips vectors have been reported to transmit five different tospoviruses in India. Their identification at an early stage is crucial in formulating appropriate pest management strategies. Since morphometric key-based thrips identification based on the adult stage is time-consuming, there is a need to develop diagnostic tools which are rapid, accurate, and independent of developmental stages. Here, we report a multiplex PCR assay to identify four major thrips vectors viz. Thrips palmi, T. tabaci, Scirtothrips dorsalis, and Frankliniella schultzei present in India.

Results: Cytochrome oxidase subunit III and internal transcribed spacer region 2 were utilized to design speciesspecific primers. Of 38 pairs of primers tested, primer pairs AG35F-AG36R, AG47F-AG48R, AG87F-AG88R, and AG79FAG80R amplified $568 \mathrm{bp}, 713 \mathrm{bp}, 388 \mathrm{bp}$, and $200 \mathrm{bp}$ products from the DNA templates of T. palmi, S. dorsalis, T. tabaci, and F. schultzei, respectively at same PCR conditions. The specificity of the primer pairs was validated with a large number of known specimens and no cross-reactivity was observed with other thrips species. The multiplex PCR assay with a cocktail of all the four primer pairs detected four thrips vectors efficiently and could discriminate all of them concurrently in a single reaction.

Conclusion: The multiplex PCR reported in this study could identify the major thrips vectors reported in India. The assay will be useful in ascertaining distribution profile of major thrips vectors, disease epidemiology, screening large samples, and quarantine.
\end{abstract}

Keywords: Thrips palmi, Thrips tabaci, Scirtothrips dorsalis, Frankliniella schultzei, Tospovirus transmission, Diagnosis

\section{Background}

The tiny, fringed-winged insects belonging to order Thysanoptera are the sole transmitters of economically damaging tospoviruses (family Tospoviridae, order Bunyav irales) in ornamental, legume, and vegetable crops. Infection of tospoviruses results in necrotic lesion, stunting, wilting, reduced yield, diminishing quality of produce, and eventually death of plant. Tospoviruses like tomato spotted wilt virus (TSWV) infects more than 900 plant species and impatiens necrotic spot virus (INSV) can be found in over 300 plant species [1]. To date, 16 thrips vectors transmitting more than 29 tospoviruses have been reported [1-4]. Among them, four thrips vectors viz. Thrips palmi Karny

\footnotetext{
* Correspondence: amal4ento@gmail.com

Insect Vector Laboratory, Advanced Centre for Plant Virology, ICAR-Indian Agricultural Research Institute, New Delhi 110012, India
}

[5, 6], Scirtothrips dorsalis Hood [7], T. tabaci Lindeman [8], and Frankliniella schultzei Trybom [7] are reported to transmit five tospoviruses in India [4]. Although F. occidentalis (Pergande) has been recently reported in India $[9,10]$, its distribution and role in spreading tospoviruses under Indian conditions are yet to be studied.

A single thrips species may transmit more than one tospovirus and mixed infestation of more than one thrips vector in a host plant is common. Therefore, identification of thrips vectors at very early stages of infestation is necessary to understand the disease epidemiology and development of appropriate pest management strategies. Since morphometric key-based identification is time consuming, laborious, skill-based, stage-specific, and cannot resolve species ambiguities, there is a need to develop molecular diagnostic techniques that are rapid, specific and independent of developmental stage. PCR-based techniques

(c) The Author(s). 2020 Open Access This article is distributed under the terms of the Creative Commons Attribution 4.0 International License (http://creativecommons.org/licenses/by/4.0/), which permits unrestricted use, distribution, and 
have proved useful for species-level identification of several thrips species using molecular markers [11-13]. Although cytochrome oxidase subunit I (COI) has been widely used for species level identification of insects, internal transcribed spacer (ITS) and cytochrome oxidase subunit III (COIII) offer additional advantages for identification of thrips at species-level because of larger interspecific distance than COI [14-17, 48]. In the present study, ITS2 and COIII sequences were utilized and a multiplex PCR assay has been successfully developed for simple, rapid, specific, and concurrent identification of major thrips vectors viz. T. palmi, S. dorsalis, T. tabaci, and F. schultzei present in India.

\section{Results}

\section{Morphometric and COI-based identification}

Based on the morphometric keys, four thrips vector species viz. T. palmi, S. dorsalis, T. tabaci, and F. schultzei were identified (Additional file 1: Figure S1) to establish the initial population. Adults of T. palmi collected from brinjal plant were pale yellow in color, had seven segmented antennae and three red color ocelli forming a triangle. Interocellar setae did not originate within the ocellar triangle. S. dorsalis adults collected from chilli plant had dark wings and dark incomplete stripes on the abdomen. The ocellar setae were between posterior ocelli and forewings had straight cilia. T. tabaci adults found on onion were whitish-yellow in color and ocelli were grey with ocellar setae within the ocellar triangle. Adults of $F$. schultzei were identified in the specimens collected from a tomato plant. In microscopic slide of $F$. schultzei, antennae were eight segmented, postocular setae were smaller than interocellar setae located along an imaginary line across the front edges of the two hind ocelli and the posteromarginal comb on abdominal segment VIII was not developed. Further, PCR with primer pair, LCO-1490 and HCO-2198 [18] amplified 560 bp of COI for each of the four thrips vectors. The BLASTn [19] analysis based on $560 \mathrm{bp}$ nucleotide sequences of COI substantiated the morphological identification with $>99 \%$ identity.

\section{Standardization of annealing temperature and PCR conditions}

Among the 12 primer pairs designed and tested for $T$. palmi by gradient PCR, only five primer pairs viz. AG35F-AG36R, AG91F-AG92R, AG93F-AG94R, AG9 5F-A96R, and AG97F-AG98R amplified a product size of $568 \mathrm{bp}, 313 \mathrm{bp}, 124 \mathrm{bp}, 191 \mathrm{bp}$, and $104 \mathrm{bp}$, respectively at an annealing temperature ranging from 55 to $65^{\circ} \mathrm{C}$. For $S$. dorsalis, 10 primer pairs were tested of which five primer pairs viz. AG47F-AG48R, AG51FAG52R, AG53F-AG54R, AG55F-56R, and AG57FAG58R amplified products of $713 \mathrm{bp}, 139 \mathrm{bp}, 166 \mathrm{bp}$,
$234 \mathrm{bp}$, and $218 \mathrm{bp}$, respectively at a temperature gradient of $55-65^{\circ} \mathrm{C}$ for annealing. In case of $T$. tabaci, of the 11 primer pairs tested in gradient PCR with $55-65^{\circ} \mathrm{C}$ annealing temperature, five primer pairs viz. AG59FAG60R, AG67F-AG68R, AG69F-AG70R, AG71F-AG7 2R, and AG87F-AG88R amplified a product size of 296 bp, $167 \mathrm{bp}, 175 \mathrm{bp}, 477 \mathrm{bp}$, and $388 \mathrm{bp}$, respectively. Only two primer pairs viz. AG75F-AG76R and AG79FAG80R out of five primer pairs tested could amplify 778 bp and $200 \mathrm{bp}$ products of F. schultzei in gradient PCR at the same range of annealing temperature mentioned above.

Based on the results of gradient PCR, $60.4{ }^{\circ} \mathrm{C}$ was considered as optimal annealing temperature to proceed multiplex PCR assay. Among the 17 species-specific primer pairs which amplified the respective thrips templates in gradient PCR, five primer pairs (AG91FAG92R, AG93F-AG94R, AG95F-AG96R for T. palmi; AG57F-AG58R for S. dorsalis; and AG69F-AG70R for T. tabaci) were not taken for further studies as their annealing temperature was either above or below $60.4{ }^{\circ} \mathrm{C}$.

\section{Cross-reactivity of species-specific primers with other thrips vectors}

The species-specific primer pairs that showed amplification in the gradient PCR at $60.4{ }^{\circ} \mathrm{C}$ were further assessed for cross-reactivity with other thrips vectors. In case of $T$. palmi, two primer pairs (AG35F-AG36R and AG97FAG98R) showed no cross-reactivity with templates of other vector species. Similarly, no cross-reactivity with other thrips templates was recorded with the primer pairs AG47F-AG48R, AG51F-AG52R, AG53F-AG54R, AG55FAG56R specific to $S$. dorsalis. The amplicon sizes of the primer pairs, AG97F-AG98R for T. palmi and those of AG51F-AG52R, AG53F-AG54R, AG55F-AG56R for $S$. dorsalis ranged from 104 to $234 \mathrm{bp}$. Considering the size of these amplicons and lack of their resolution in agarose gel electrophoresis, these primer pairs were not considered in multiplex PCR to avoid misinterpretation of the results. Primer pairs AG35F-AG36R and AG47F-AG48R yielding amplicons of $568 \mathrm{bp}$ and $713 \mathrm{bp}$, respectively were undertaken for concurrent detection of T. palmi and $S$. dorsalis. In case of T. tabaci, all the primer pairs except primer pair AG87F-AG88R were found cross-reactive with other thrips vectors. Two F. schultzei-specific primers (AG75F-AG76R and AG79F-AG80R) amplified products of $788 \mathrm{bp}$ and $200 \mathrm{bp}$. Keeping in mind the size of other amplicons in triplex PCR described above, primer pair AG75F-AG76R was the first choice for multiplex PCR but found to be cross-reactive with other thrips templates. Hence, the other primer pair for F. schultzei (AG79FAG80R) was tested and no cross-reactivity was recorded. Finally, the four species-specific primer pairs i.e. AG47FAG48R (derived from COIII), AG35F-AG36R, AG87- 


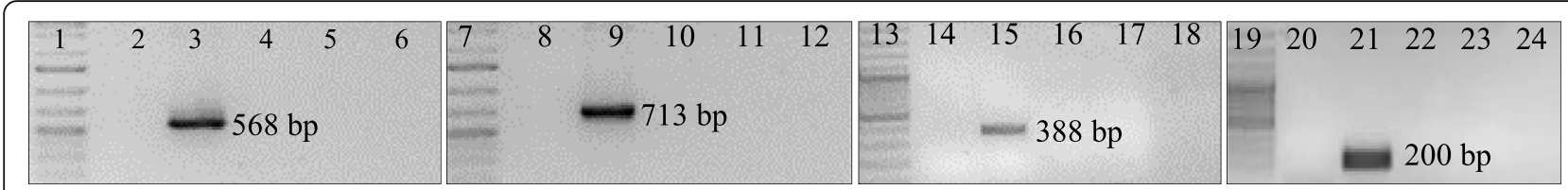

Fig. 1 Assessment of cross-reactivity of four species-specific primer pairs. Primer pairs viz. AG35F-AG36R, AG47F-AG48R, AG87F-AG88R, and AG79F-AG80R specific to T. palmi, S. dorsalis, T. tabaci, and F. schultzei, respectively were shortlisted for multiplex PCR assay. The cross-reactivity of the species-specific primer pairs was assessed in $25 \mu \mathrm{l} \mathrm{PCR} \mathrm{reactions} \mathrm{and} \mathrm{resolved} \mathrm{on} \mathrm{0.8 \%} \mathrm{agarose} \mathrm{gel} \mathrm{electrophoresis.} \mathrm{Lane} \mathrm{1,} \mathrm{7:} 1 \mathrm{~kb}$ plus DNA ladder; Lane 13, 19: 100 bp plus DNA ladder; Lane 2, 8, 14, 20: water control; Lane 3-6: PCR amplicons using T. palmi-specific primer pair with DNA templates of T. palmi (3), S. dorsalis (4), T. tabaci (5), and F. schultzei (6); Lane 9-12: PCR amplicons using S. dorsalis-specific primer pair with DNA templates of S. dorsalis (9), T. palmi (10), T. tabaci (11) and F. schultzei (12); Lane 15-18: PCR amplicons using T. tabaci-specific primer pair with DNA templates of T. tabaci (15), T. palmi (16), S. dorsalis (17), and F. schultzei (18); Lane 21-24: PCR amplicons using F. schultzei-specific primer pair with DNA templates of F. schultzei (21), T. palmi (22), S. dorsalis (23), and T. tabaci (24). PCR with primer pairs AG35F-AG36R, AG47F-AG48R, AG87F-AG88R, and AG79F-AG80R produced bands of 568 bp, $713 \mathrm{bp}, 388 \mathrm{bp}$, and $200 \mathrm{bp}$ of T. palmi, S. dorsalis, T. tabaci, and F. schultzei,

respectively. No cross-reactivity was found with other thrips vectors

AG88R, and AG79F-AG80R (derived from ITS2) which did not show any cross-reactivity with other thrips vectors (Fig. 1) were considered for concurrent detection of four thrips vectors by multiplex PCR.

\section{Multiplex PCR assay}

The duplex PCR assay performed with a cocktail of AG35F-AG36R and AG47F-AG48R specific to T. palmi and $S$. dorsalis, respectively amplified desired products of $568 \mathrm{bp}$ and $713 \mathrm{bp}$ and was able to discriminate between T. palmi and S. dorsalis (Additional file 2: Figure S2). Triplex PCR using a cocktail of primer pairs AG35F-AG36R, AG47F-AG48R, and AG87F-AG88R amplified $568 \mathrm{bp}, 713 \mathrm{bp}$, and $388 \mathrm{bp}$ products of $T$. palmi, S. dorsalis, and T. tabaci, respectively. The triplex PCR was able to discriminate three thrips vectors individually and all of them in a single reaction (Additional file 3: Figure S3). The multiplex PCR to identify all the four thrips vectors viz. T. palmi, S. dorsalis, T. tabaci, and F. schultzei using a cocktail of AG35FAG36R, AG47F-AG48R, AG87F-AG88R, and AG79FAG80R primers yielded products of $568 \mathrm{bp}, 713 \mathrm{bp}, 388$ bp, and $200 \mathrm{bp}$. The multiplex PCR efficiently discriminated four thrips vectors individually and concurrently even in a single reaction when DNA templates of all four thrips vectors were mixed at a final concentration of 50

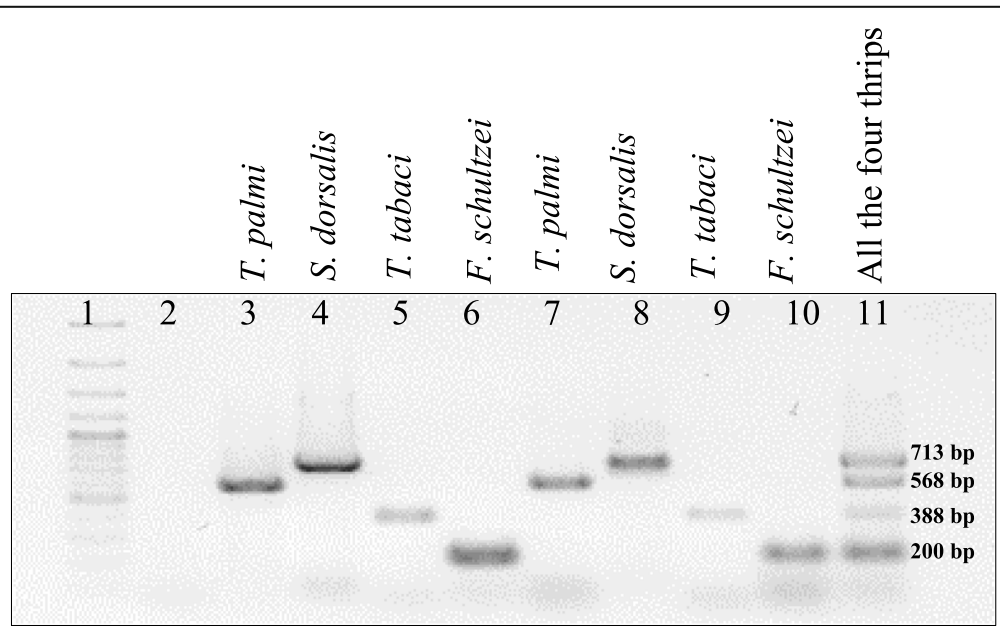

Fig. 2 Multiplex PCR assay to identify four thrips vectors concurrently. Multiplex PCR was performed using a cocktail of the four specific-specific primer pairs viz. AG35F-AG36R, AG47F-AG48R, AG87F-AG88R, and AG79F-AG80R for T. palmi, S. dorsalis, T. tabaci, and F. schultzei with the templates of the four thrips vectors separately and mixed templates of all four thrips vectors. Lane 1: $100 \mathrm{bp}$ plus DNA ladder; Lane 2: water control; Lane 3-6: PCR amplicons using species-specific primers with DNA templates of respective thrips vectors, T. palmi (3), S. dorsalis (4), T. tabaci (5), and F. schultzei; Lane 7-11: PCR amplicons using cocktails of primer pairs specific to T. palmi, S. dorsalis, T. tabaci, and F. schultzei with DNA templates of T. palmi (7), S. dorsalis (8), T. tabaci (9), F. schultzei (10), and mixed templates of all four thrips vectors (11). The multiplex PCR using a cocktail of all four thrips vectors amplified products of $568 \mathrm{bp}, 713 \mathrm{bp}, 388 \mathrm{bp}$, and $200 \mathrm{bp}$ of T. palmi, S. dorsalis, T. tabaci, and F. schultzei, respectively. The multiplex PCR efficiently discriminated four thrips vectors individually and even in a single reaction when DNA templates of all four thrips vectors were mixed 
ng (Fig. 2). The BLASTn analyses of the sequences of each PCR product further validated the specificity of the reactions with $>98 \%$ identity.

\section{Validation of multiplex PCR assay}

The multiplex PCR was validated over more than 80 reactions with known thrips specimens. The results confirmed the test-retest reliability and reproducibility of the assay. The multiplex PCR assay using the primer cocktail of four species-specific primers pairs (AG35FAG36R, AG47F-AG48R, AG87-AG88R, and AG79FAG80R) was employed to identify the thrips vectors in more than 30 collections from natural vegetation. The assay showed two amplicons of $713 \mathrm{bp}$ and $568 \mathrm{bp}$ with DNA templates of thrips collected from soybean and mungbean plants indicating a mixed infestation of $S$. dorsalis and T. palmi in these crops (Fig. 3). The multiplex PCR assay with template of thrips vectors collected from groundnut, chilli, and watermelon plants amplified products of $713 \mathrm{bp}$ that confirmed the presence of $S$. dorsalis in groundnut, chilli, and watermelon plants. Similarly, multiplex PCR produced an amplicon of 568 bp and detected the incidence of T. palmi on brinjal, lettuce, and tomato plants. The assay confirmed the presence of $T$. tabaci as a $388 \mathrm{bp}$ amplicon was produced when tested with the templates of thrips collected from onion plants. The nucleotide sequence homology analyses of a few representative PCR products showed > 99\% identity with the respective thrips vector species that reconfirmed the efficiency of the assay.

\section{Discussion}

Thrips remain major insect pests in vegetables and ornamental plants [20-22]. Besides inflicting direct damages to crops, they transmit deadly tospoviruses. Although the persistent-propagative transmission of tospoviruses by thrips [23] is considered to be specific to virus-vector combination, one thrips vector species can transmit more than one tospovirus [2, 3]. T. palmi and F. occidentalis are reported to transmit seven different tospoviruses [3, 49]. Transmission of more than one tospovirus is also evident by $F$. schultzei, S. dorsalis, and T. tabaci [3]. Infestation of more than one thrips vector in the same host plant has intensified the complexity of the situation. An economic crop like groundnut hosts both T. palmi and S. dorsalis [24]. More than one thrips vector is also reported in tomato [25], watermelon [26], and soybean [27]. Therefore, development of appropriate methods for fast and concurrent identification of these thrips vectors at an early stage of infestation seems to be essential, especially when they are minute and cryptic in nature and spreading diseases [11, 12, 28]. Morphometric key-based identification of thrips species is timetaking, labor-intensive, requires expertise, and dependent on developmental stage as only adults can be identified. The speed, reproducibility, and accuracy of molecular techniques have made them a valuable tool for identification of thrips vectors [13, 29-36]. The simultaneous identification of several species using multiplex PCR has become popular for its added advantages of saving time, money, and effort over other methods of diagnosis [37, 38].

In India, four thrips vectors viz. T. palmi, S. dorsalis, T. tabaci, and F. schultzei have been reported so far to transmit five tospoviruses such as groundnut bud necrosis virus (GBNV), watermelon bud necrosis virus (WBNV), peanut yellow spot virus (PYSV), capsicum chlorosis virus (CaCV) and Irish yellow spot virus (IYSV) [4]. Recently F. occidentalis, a potential vector of TSWV has been reported from the Nilgiri hills of India $[9,10]$.

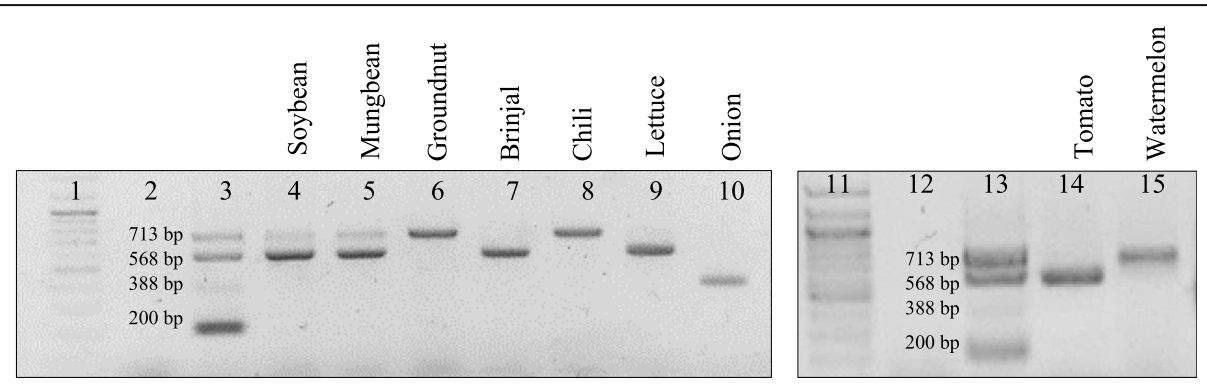

Fig. 3 Identification of thrips vectors collected from different crops using multiplex assay. Thrips were collected from brinjal, chilli, onion, lettuce, groundnut, and mungbean plants. Multiplex PCR assay using all four thrips vector-specific primer pairs was performed with DNA templates of thrips collected from different crops. Lane 1, 11: 100 bp plus DNA ladder; Lane 2, 12: water control; Lane 3, 13: multiplex PCR products with mixed templates of all four thrips vectors as positive control; Lane 4-10, 14, 15: multiplex PCR product with template of thrips collected from soybean (4), mungbean (5), groundnut (6), brinjal (7), chilli (8), lettuce (9), onion (10), tomato (14), and watermelon (15). The multiplex PCR assay showed two amplicons of $713 \mathrm{bp}$ and $568 \mathrm{bp}$ with DNA templates of thrips collected from soybean and mungbean plants indicating mixed infestation of S. dorsalis and T. palmi. A product of $713 \mathrm{bp}$ with template of thrips vectors collected from groundnut, chilli, and watermelon plants confirmed the presence of $S$. dorsalis. Amplification of $568 \mathrm{bp}$ product with thrips templates of brinjal, lettuce, and tomato indicated the presence of $T$. palmi, whereas T. tabaci was identified from onion producing $388 \mathrm{bp}$ band 
Probably, its presence is restricted in that region and role in spreading tospovirus under Indian conditions is yet to be studied. The present study reports a multiplex PCR-based assay for simultaneous identification of four major thrips vectors viz. T. palmi, S. dorsalis, T. tabaci, and $F$. schultzei reported in India.

COI is the most extensively used for identification of insect species due to its wide acceptance as a universal barcode [18, 39, 40]. In case of thrips, COI is hypervariable and considered for haplotype or cryptic species determination [14-17, 48], whereas COIII and ITS regions provide additional advantages at species-level identification due to larger interspecific distance than COI $[14,41]$. In the present study, ITS2 and COIII sequences were used to design species-specific primers of the four thrips vectors. Out of 38 species-specific primer pairs designed and tested, four primer pairs derived from ITS2 (AG35F-AG36R, AG87F-AG88R, and AG79FAG80R) and COIII (AG47F-AG48R) were found suitable to discriminate T. palmi, T. tabaci, F. schultzei, and S. dorsalis at same PCR conditions. ITS-based markers have been used by various researchers for species-level identification of thrips $[11,12,29,42]$. The four speciesspecific primer pairs viz. AG35F-AG36R, AG47FAG48R, AG87F-AG88R, and AG79F-AG80R for $T$. palmi, S. dorsalis, T. tabaci, and F. schultzei used in the present investigation were not cross-reactive and used to carry out concurrent detection of thrips vectors by multiplex PCR. Multiplex PCR has been widely used by various researchers for rapid and simultaneous identification of thrips vectors [28, 34, 38, 41]. However, the present study is unique in the sense that, this is the first effort in concurrent identification of all the major thrips vectors present in India. The multiplex PCR assay reported here was employed to identify thrips vectors collected from the different crops under natural conditions. The assay diagnosed mixed infection of T. palmi and $S$. dorsalis in soybean and mungbean plants. T. palmi was also identified from the samples collected from brinjal, lettuce, and tomato plants using this assay. The multiplex assay was also found efficient to identify $S$. dorsalis in groundnut, chilli, and watermelon and T. tabaci in onion plants.

\section{Conclusions}

The multiplex PCR assay-based technique developed in the present study will be helpful in rapid and simultaneous identification of major thrips vectors transmitting deadly tospoviruses in India. The assay will be helpful in determining the distribution profile of major thrips vectors and understanding disease epidemiology. The assay will facilitate early detection of the thrips vectors to support formulation of suitable management strategies against thrips vectors and tospoviruses. Further, the technique described in the present study can be applied in resistance screening and quarantine.

\section{Methods \\ Sample collection and identification}

The initial population of adult thrips was collected in plastic bags from different host plants such as brinjal, chilli, onion, and tomato from the experimental fields of Indian Agricultural Research Institute (IARI), New Delhi $\left(28.6377^{\circ} \mathrm{N}, 77.1571^{\circ} \mathrm{E}\right.$, and $228.61 \mathrm{~m}$ above MSL) and taken to the laboratory. Microscopic slides were then prepared following the protocol of Silveria and Haro [43] and the thrips vectors were at first identified based on the standard morphometric keys [44, 45]. Morphological characters like antennal segments, color, body shape and size, and position of ocellar setae were taken into consideration. Further, the identity of the initial population of $T$. palmi, S. dorsalis, T. tabaci, and F. schultzei was confirmed based on nucleotide sequences of COI. Total DNA from morphologically identified single adult of thrips vectors was extracted using DNeasy Blood and Tissue Kit (Qiagen) following the manufacturer's protocol. The PCR was carried out as described by Ghosh et al. [46] using the primer pair LCO-1490 and HCO-2198 [18] derived from COI region in a Himedia Prima Duo Thermocycler. The $25 \mu \mathrm{l} \mathrm{PCR} \mathrm{mixture}$ contained 20-30 ng DNA, $2.5 \mu \mathrm{l}$ 10X PCR buffer (Thermo Scientific), $0.4 \mu \mathrm{M}$ each forward and reverse primer, $260 \mu \mathrm{M}$ dNTP (Thermo Scientific) and $2 \mathrm{U}$ DreamTaq polymerase (Thermo Scientific). The following PCR conditions were used: $94{ }^{\circ} \mathrm{C}$ for $5 \mathrm{~min}, 35$ cycles of $94{ }^{\circ} \mathrm{C}$ for $30 \mathrm{~s}, 54^{\circ} \mathrm{C}$ for $1 \mathrm{~min} 30 \mathrm{~s}$, and $72{ }^{\circ} \mathrm{C}$ for 1 min followed by $72{ }^{\circ} \mathrm{C}$ for $10 \mathrm{~min}$. The amplified PCR products were eluted, cloned and sequenced to confirm the identity of initial population. The sequences were edited by BioEdit [47] and verified by BLASTn [19] for species homology.

\section{Development of iso-female lines of thrips vectors}

A single adult female of T. palmi, S. dorsalis, T. tabaci, and F. schultzei identified based on morphometric keys and confirmed by COI nucleotide sequence identity was released on healthy brinjal, chilli, onion, and tomato plants, respectively within insect rearing cages $(40 \mathrm{~cm} *$ $27 \mathrm{~cm} * 60 \mathrm{~cm}$ ) to develop iso-female population of each thrips vector. The plants were grown in plastic pots filled with soilrite and supplied to the thrips. Nutrient solution was provided in a plastic tray on to which the pots were placed and covered by the insect rearing cage. The population was maintained under controlled environmental conditions at $28 \pm 1{ }^{\circ} \mathrm{C}$ temperature, $60 \pm 10 \%$ relative humidity, and $8 \mathrm{~h}$ dark. Fresh plants were provided in the cages as and when required. The population of each thrips vector was regularly monitored for the 
presence of natural enemies and other thrips species. The purity of the population was checked from time to time by sequencing $\mathrm{COI}$ as described above. Adults were collected from the respective iso-female generation with a fine Camel hairbrush for further experiments.

\section{Designing species-specific primers and standardization of annealing temperature by gradient PCR}

For developing species-specific PCR, 38 species-specific primer pairs were designed based on the sequence polymorphism of ITS2 and COIII regions (Additional file 4: Table S1). All known template sequences available in the National Center for Biotechnology Information (NCBI) were utilized for primer designing. The major aspects such as sequence specificity, melting temperature, intra-primer or inter-primer homology were considered for primer designing. Sites with mismatch at 3 '-end sequences among the congeneric thrips species were targeted to design the species-specific primers. The sitespecificity of the primers was verified by performing BLASTn [19] with available template sequences in NCBI.

Total DNA from respective thrips vectors was extracted as described above. Gradient PCR was performed for each primer pair with DNA template of respective thrips vector to standardize the annealing temperature. The PCR was carried out in $25 \mu \mathrm{l}$ reaction volume containing $\sim 50 \mathrm{ng}$ DNA, $2.5 \mu \mathrm{l} 10 \mathrm{X}$ PCR buffer (Thermo Scientific), $0.4 \mu \mathrm{M}$ each forward and reverse primer, $260 \mu \mathrm{M}$ dNTPs (Thermo Scientific) and $2 \mathrm{U}$ DreamTaq polymerase (Thermo Scientific). Following reaction conditions were followed, initial denaturation at $94{ }^{\circ} \mathrm{C}$ for 5 min, then 35 cycles at $94{ }^{\circ} \mathrm{C}$ for $30 \mathrm{~s}$, annealing at a range of $55-65^{\circ} \mathrm{C}$ for $45 \mathrm{~s}$, and $72{ }^{\circ} \mathrm{C}$ for $30 \mathrm{~s}$ followed by a final extension at $72{ }^{\circ} \mathrm{C}$ for $10 \mathrm{~min}$. The PCR products were resolved on $0.8 \%$ agarose gel stained with GoodView (BR Biochem) and visualized using a gel documentation system (MasteroGen Inc. Taiwan). The optimal annealing temperature for each primer pair was selected based on the resolution of amplified products in agarose gel.

\section{Cross-reactivity assessment of species-specific primers}

Based on the results of gradient PCR, few primer pairs of each thrips vector that could amplify at the same annealing temperature were shortlisted. The shortlisted primer pairs with respect to each thrips vector were assessed for cross-reactivity with DNA templates of other three thrips vectors. To start with the crossreactivity of $T$. palmi-specific primer pairs, AG35FAG36R and AG91F-92R were tested with the DNA templates of S. dorsalis, T. tabaci, and F. schultzei and the cross-reactivity of $S$. dorsalis-specific primer pairs viz. AG47F-AG48R and AG55F-56R was verified with $T$. palmi, T. tabaci, and F. schultzei templates. Similarly, PCR was performed with T. palmi, S. dorsalis, and F. schultzei templates using T. tabaci-specific primer pairs viz. AG59F-AG60R, AG71F-AG72R, and AG87FAG88R. F. schultzei-specific primer pairs viz. AG75FAG76R and AG79F-AG80R were tested with T. palmi, S. dorsalis, and T. tabaci templates to check the crossreactivity. PCR was set up in $25 \mu \mathrm{l}$ reaction mixture and resolved on $0.8 \%$ agarose gel electrophoresis as described above. The primer pairs that showed any amplification with DNA templates of other three thrips vectors were not considered in next steps. The primer pairs that were not cross-reactive and the PCR products were well resolved in agarose gel, taken in multiplex PCR assay.

\section{Multiplex PCR assay for concurrent identification of thrips vectors}

Based on the results of gradient PCR, cross-reactivity assay and amplicon sizes, a duplex PCR was performed at first by using a mix of T. palmi- and S. dorsalis-specific primer pairs viz. AG35F-AG36R and AG47FAG48R, respectively with DNA templates of $T$. palmi and $S$. dorsalis in separate PCR tubes. Same PCR conditions were maintained as described above. A triplex PCR assay was performed by using a cocktail of primer pairs viz. AG35F-AG36R, AG47F-AG48R, and AG87F-AG88R specific to T. palmi, S. dorsalis, and T. tabaci, respectively with templates of $T$. palmi, S. dorsalis, and T. tabaci separately at above-mentioned PCR conditions. Further, templates of T. palmi, S. dorsalis, and T. tabaci were mixed together and $50 \mathrm{ng}$ of the mixed DNA was used in the triplex PCR to test the efficacy of the assay in simultaneous detection of three thrips vectors.

After successful attempts of the triplex PCR, a multiplex PCR was performed which comprised of a cocktail of the four primer pairs viz. AG35F-AG36R, AG47FAG48R, AG87F-AG88R, and AG79F-AG80R specific to T. palmi, S. dorsalis, T. tabaci, and F. schultzei in PCR tubes containing the templates of the four thrips vectors separately. The multiplex PCR assay was further tested to detect all the four thrips vectors simultaneously in a single reaction. PCR was conducted using a cocktail of all four species-specific primers described above. DNA templates of all four thrips vectors were mixed to a final concentration of $50 \mathrm{ng}$ keeping other PCR conditions same as mentioned above. Amplified PCR products in the multiplex assay were eluted after agarose gel electrophoresis, cloned, and sequenced to validate the specificity of the reactions. The sequences were processed by BioEdit [47] and species homology was verified by BLASTn [19].

\section{Validation of multiplex PCR assay}

The multiplex PCR assay was validated by using a large number of known specimens. To check the efficiency of 
the assay in identifying thrips vectors collected from natural vegetation, samples were collected separately from different plants such as brinjal, chilli, onion, lettuce, groundnut, mungbean, tomato, and watermelon from experimental fields of IARI. Thrips were grouped cropwise and taken to the laboratory. Total DNA was extracted from a group of thrips as described above. Multiplex PCR was performed using the cocktail of all four thrips vector-specific primer pairs with DNA templates of thrips collected from different crops. DNA of four known thrips vectors were mixed and used as positive control and marker. PCR reaction mixture and conditions remained same as mentioned above taking $50 \mathrm{ng}$ DNA template for each reaction. The PCR amplified products were run in $0.8 \%$ agarose gel electrophoresis and visualized in a gel documentation system. The sizes of the amplified products were compared with a $100 \mathrm{bp}$ plus DNA ladder (Thermo Scientific) and PCR products of known thrips vectors used as marker. Representative PCR amplicons were cloned and sequenced to revalidate the results.

\section{Supplementary information}

Supplementary information accompanies this paper at https://doi.org/10. 1186/s12864-020-6560-x.

Additional file 1 Figure S1. Dorsal view of adult thrips vectors (a) $T$. palmi, (b) S. dorsalis, (c) T. tabaci, and (d) F. schultzei. The microscopic slides were prepared following Silveria and Haro [43]. The thrips vectors were at first identified based on the standard morphometric keys following Bhatti [44], and Cluever and Smith [45] and further confirmed by cytochrome oxidase subunit I sequences.

Additional file 2 Figure S2. Duplex PCR to identify T. palmi and S. dorsalis. Duplex PCR was performed by mixing T. palmi and S. dorsalisspecific primer pairs viz. AG35F-AG36R, and AG47F-AG48R with DNA templates of T. palmi and S. dorsalis. Lane 1: 500 bp DNA ladder; Lane 2: water control; Lane 3: PCR amplicon using primer mixer with DNA template of T. palmi; Lane 4: PCR amplicon using primer mixer with DNA template of S. dorsalis. The duplex PCR assay amplified $568 \mathrm{bp}$, and 713 bp products of T. palmi and S. dorsalis and was able to efficiently discriminate between T. palmi and $S$. dorsalis.

Additional file $\mathbf{3}$ Figure $\mathbf{S 3}$. Triplex PCR assay to identify three thrips vectors concurrently. A triplex PCR assay was performed using a cocktail of primer pairs viz. AG35F-AG36R, AG47F-AG48R, and AG87F-AG88R specific to T. palmi, S. dorsalis, and T. tabaci, respectively with templates of $T$. palmi, S. dorsalis, and T. tabaci separately and mixed templates of T. palmi, S. dorsalis, and T. tabaci. Lane 1: 100 bp plus DNA ladder; Lane 2: water control; Lane 3-5: PCR amplicons using cocktails of primer pairs specific to T. palmi, S. dorsalis, and T. tabaci with DNA templates of T. palmi (3), S. dorsalis (4), T. tabaci (5), and mixed templates of three thrips vectors (6). Triplex PCR amplified $568 \mathrm{bp}, 713 \mathrm{bp}$, and $388 \mathrm{bp}$ products of T. palmi, S. dorsalis, and T. tabaci, respectively. The triplex PCR was able to discriminate three thrips vectors individually and all of them in a single reaction.

Additional file $\mathbf{4}$ Table $\mathbf{S 1}$. Species-specific primer pairs tested for identification of four thrips vectors

\section{Abbreviations}

BLAST: Basic local alignment search tool; CaCV: Capsicum chlorosis virus; COI: Cytochrome oxidase subunit I; COIII: Cytochrome oxidase subunit III; GBNV: Groundnut bud necrosis virus; IARI: Indian Agricultural Research Institute; INSV: Impatiens necrotic spot virus; ITS: Internal transcribed spacer; IYSV: Irish yellow spot virus; NCBI: National Center for Biotechnology
Information; PYSV: Peanut yellow spot virus; TSWV: Tomato spotted wilt virus; WBNV: Watermelon bud necrosis virus

\section{Acknowledgments}

The authors thank Dr. Sunil Kumar Mukherjee and Dr. Bikash Mandal (IARI) for suggesting improvements to the work. We also thank the Editor and anonymous reviewers for critically reading the manuscript and suggesting substantial improvements.

\section{Authors' contributions}

AG conceived and designed research. SJ and AM conducted experiments. HD conducted morphometric key-based identification. SJ, AG, and RKJ analyzed data. SJ wrote the draft manuscript. AG and RKJ wrote and edited the final manuscript. All authors read and approved the manuscript.

\section{Funding}

The financial support received from IARI, DBT (BT/PR26136/AGIII/103/1005/ 2018), and SERB (EMR/2017/000590) is thankfully acknowledged. The funding bodies played no role in the design of the study and collection, analysis, and interpretation of data and in writing the manuscript.

\section{Availability of data and materials}

The datasets generated and/or analysed during the current study are available in NCBI database and can be accessed using the accession numbers MN594549, MN194202, MN594551, MN187366, MN193061, MN594550, MN594552, and MT012390.

Ethics approval and consent to participate

The samples were collected by the authors from experimental farm of IARI, New Delhi with permission.

\section{Consent for publication}

Not applicable.

\section{Competing interests}

The authors declare that they have no competing interests.

Received: 19 October 2019 Accepted: 6 February 2020

Published online: 18 February 2020

\section{References}

1. Pappu HR, Jones RAC, Jain RK. Global status of tospovirus epidemics in diverse cropping systems: successes achieved and challenges ahead. Virus Res. 2009;141:219-36.

2. Riley DG, Joseph SV, Srinivasan R, Diffie S. Thrips vectors of tospoviruses. J Integr Pest Manag. 2011:2:1-10.

3. Rotenberg $D$, Jacobson AL, Schneweis DJ, Whitfield AE. Thrips transmission of tospoviruses. Curr Opin Virol. 2015;15:80-9.

4. Ghosh A, Dey D, Timmanna B, Mandal B, Jain RK. Thrips as the vectors of tospoviruses in Indian agriculture. A Century of Plant Virology in India. Singapore: Springer; 2017. p. 537-61.

5. Palmer JM, Reddy DVR, Wightman JA, GVR R. New information on the thrips vectors of tomato spotted wilt virus in groundnut crops in India. Int Arachis Newsl. 1990;7:24-5 Legumes Program, ICRISAT.

6. Lakshmi KV, Wightman JA, Reddy DVR, Rao GVR, Buiel AAM, Reddy DDR Transmission of peanut bud necrosis virus by Thrips palmi in India, Thrips Biology and Management. Boston, MA: Springer US: 1995. p. 179-84.

7. Amin PW, Reddy DVR, Ghanekar AM. Transmission of tomato spotted wilt virus, the causal agent of bud necrosis of peanut, by Scirtothrips dorsalis and Frankliniella schultzei. Plant Dis. 1981;65:663-5.

8. Meena RL, Ramasubram T, Venkatesan S, Mohankumar S. Molecular characterization of tospovirus transmitting thrips populations from India. Am J Biochem Biotechnol. 2005;1:167-72.

9. Tyagi K, Kumar V. Thrips (Insecta: Thysanoptera) of India- an updated checklist. Halteres. 2016;7:64-98.

10. Suganthy M, Rageshwari S, Senthilraja C, Nakkeeran S, Malathi VG. New record of western flower thrips, Frankliniella occidentalis (Pergande) (Thysanoptera: Thripidae) in South India. Int J Environ Agric Biotechnol. 2016; 1:857-67. 
11. Farris RE, Ruiz-Arce R, Ciomperlik M, Vasquez JD, DeLeón R. Development of a ribosomal DNA ITS2 marker for the identification of the thrips, Scirtothrips dorsalis. J Insect Sci. 2010;10:1-15.

12. de Grazia A, Marullo R, Moritz G. Molecular diagnosis of native and quarantine pest thrips of southern European citrus orchards. Bull Insectology. 2016;69:1-6.

13. Wang H, Kennedy GG, Reay-Jones FPF, Reisig DD, Toews MD, Roberts PM, Herbert DA Jr, Taylor S, Jacobson AL, Greene JK. Molecular identification of thrips species infesting cotton in the southeastern United States. J Econ Entomol. 2018;111:892-8.

14. Glover RH, Collins DW, Walsh K, Boonham N. Assessment of loci for DNA barcoding in the genus thrips (Thysanoptera:Thripidae). Mol Ecol Resour. 2010;10:51-9.

15. Rebijith KB, Asokan R, Krishna V, Ranjitha HH, Krishna Kumar NK, Ramamurthy W. DNA barcoding and elucidation of cryptic diversity in thrips (Thysanoptera). Florida Entomol. 2014;97:1328-47.

16. Iftikhar R, Ashfaq M, Rasool A, Hebert PDN. DNA barcode analysis of thrips (Thysanoptera) diversity in Pakistan reveals cryptic species complexes. PLoS One. 2016;11:e0146014.

17. Tyagi K, Kumar V, Singha D, Chandra K, Laskar BA, Kundu S, Chakraborty R, Chatterjee S. DNA barcoding studies on thrips in India: cryptic species and species complexes. Sci Rep. 2017;7:1-14.

18. Folmer O, Black M, Hoeh W, Lutz R, Vrijenhoek R. DNA primers for amplification of mitochondrial cytochrome oxidase subunit I from diverse metazoan invertebrates. Mol Mar Biol Biotechnol. 1994;3:294-9.

19. Altschul SF, Madden TL, Schäffer AA, Zhang J, Zhang Z, Miller W, Lipman DJ. Gapped BLAST and PSI-BLAST: a new generation of protein database search programs. Nucleic Acids Res. 1997;25:3389-402.

20. Parrella G, Gognalons P, Gebre-Selassiè K, Vovlas C, Marchoux G. An update of the host range of tomato spotted wilt virus. J Plant Pathol. 2003;85:227-64.

21. Zhang Z-J, Wu Q-J, Li X-F, Zhang Y-J, Xu B-Y, Zhu G-R. Life history of western flower thrips, Frankliniella occidentalis (Thysanoptera: Thripae), on five different vegetable leaves. J Appl Entomol. 2007;131:347-54.

22. Gill HK, Garg H, Gill AK, Gillett-Kaufman JL, Nault BA. Onion thrips (Thysanoptera: Thripidae) biology, ecology, and management in onion production systems. J Integr Pest Manag. 2015;6:6-6.

23. Ullman DE, Sherwood JL, German TL. Thrips as vectors of plant pathogens. In: Lewis T, editor. Thrips as crop pest; 1997. p. 539-65.

24. Srinivasan R, Abney MR, Lai P-C, Culbreath AK, Tallury S, Leal-Bertioli SCM. Resistance to thrips in peanut and implications for management of thrips and thrips-transmitted orthotospoviruses in peanut. Front Plant Sci. 2018;9:1604

25. Macharia I, Backhouse D, Skilton R, Ateka E, Wu S, Njahira M, Maina S, Harvey J. Diversity of thrips species and vectors of tomato spotted wilt virus in tomato production systems in Kenya. J Econ Entomol. 2015;108:20-8.

26. Costa EM, de Lima MGA, Junior RS, Cavalleri A, Araujo EL. Thrips collected in watermelon crops in the semiarid of Rio Grande do Norte, Brazil. Ciência Rural. 2015;45:575-7

27. Viteri D, Cabrera I, Estévez De Jensen C. New record of thrips species associated with soybeans in Puerto Rico. Florida Entomol. 2009;92:181-5.

28. Sabahi S, Fekrat L, Zakiaghl M. A simple and rapid molecular method for simultaneous identification of four economically important thrips species. J Agric Sci Technol. 2017;19:1279-90.

29. Toda S, Komazaki S. Identification of thrips species (Thysanoptera: Thripidae) on Japanese fruit trees by polymerase chain reaction and restriction fragment length polymorphism of the ribosomal ITS2 region. Bull Entomol Res. 2002;92:359-63.

30. Brunner PC, Fleming C, Frey JE. A molecular identification key for economically important thrips species (Thysanoptera: Thripidae) using direct sequencing and a PCR-RFLP-based approach. Agric For Entomol. 2002;4: 127-36.

31. Kox LFF, van den Beld HE, Zijlstra C, Vierbergen G. Real-time PCR assay for the identification of Thrips palmi. EPPO Bull. 2005;35:141-8.

32. Walsh K, Boonham N, Barker I, Collins DW. Development of a sequencespecific real-time PCR to the melon thrips Thrips palmi (Thysanoptera: Thripidae). J Appl Entomol. 2005;129:272-9.

33. Mehle N, Trdan S. Traditional and modern methods for the identification of thrips (Thysanoptera) species. J Pest Sci. 2012;85:179-90.

34. Nakahara S, Minoura K. Identification of four thrips species (Thysanoptera: Thripidae) by multiplex polymerase chain reaction. Res Bull Plant Prot Japan. 2015;42:37-42.
35. Przybylska A, Fiedler Ż, Obrępalska-Stęplowska A. PCR-RFLP method to distinguish Frankliniella occidentalis, Frankliniella intonsa, Frankliniella pallida and Frankliniella tenuicornis. J Plant Prot Res. 2016;56:60-6.

36. Przybylska A, Fiedler Ż, Frąckowiak P, Obrępalska-Stęplowska A. Real-time PCR assay for distinguishing Frankliniella occidentalis and Thrips palmi. Bull Entomol Res. 2018;108:413-20.

37. Saccaggi DL, Krüger K, Pietersen G. A multiplex PCR assay for the simultaneous identification of three mealybug species (Hemiptera: Pseudococcidae). Bull Entomol Res. 2008;98:27-33.

38. Yeh WB, Tseng MJ, Chang NT, Wu SY, Tsai YS. Agronomically important thrips: development of species-specific primers in multiplex PCR and microarray assay using internal transcribed spacer 1 (ITS1) sequences for identification. Bull Entomol Res. 2015;105:52-9.

39. Hebert PDN, Cywinska A, Ball SL, de Waard JR. Biological identifications through DNA barcodes. Proc Biol Sci. 2003;270:313-21.

40. Hebert PDN, Ratnasingham S, de Waard JR. Barcoding animal life: cytochrome oxidase subunit 1 divergences among closely related species. Proc Biol Sci. 2003;270(Suppl 1):S96-9.

41. Yeh WB, Tseng MJ, Chang NT, Wu SY, Tsai YS. Development of speciesspecific primers for agronomical thrips and multiplex assay for quarantine identification of western flower thrips. J Econ Entomol. 2014;107:1728-35.

42. Kumar V, Dickey A, Seal D, Shatters R, Osborne L, McKenzie C. Unexpected high intragenomic variation in two of three major pest thrips species does not affect ribosomal internal transcribed spacer 2 (ITS2) utility for thrips identification. Int J Mol Sci. 2017;18:2100.

43. Silveria LCP, Haro MM. Fast slide preparation for thrips (Thysanoptera) routine identifications. Eur J Entomol. 2016;113:403-8.

44. Bhatti JS. Species of the genus thrips from India (Thysanoptera). Syst Entomol. 1980;5:109-66

45. Cluever JD, Smith HA. A photo-based key of thrips (Thysanoptera) associated with horticultural crops in Florida. Florida Entomol. 2017;100:454-67.

46. Ghosh A, Das A, Lepcha R, Mandal B. Identification, distribution and temporal occurrence of aphids infesting large cardamom and their efficiency in transmitting large cardamom viruses in northeastern subHimalayan region. Australas Plant Pathol. 2016:45:533-6.

47. Hall TA. BioEdit: a user-friendly biological sequence alignment editor and analysis program for windows 95/98/NT. Nucleic Acids Symp Ser. 1999;41:95-8.

48. Amalendu Ghosh, Shounak S. Jagdale, Basavaraj, Ralf G. Dietzgen, Rakesh Kumar Jain, (2020) Genetics of Thrips palmi (Thysanoptera: Thripidae). Journal of Pest Science 93 (1):27-39.

49. Amalendu Ghosh, Y. B. Basavaraj, Sumit Jangra, Amrita Das, (2019) Exposure to watermelon bud necrosis virus and groundnut bud necrosis virus alters the life history traits of their vector, Thrips palmi (Thysanoptera: Thripidae). Archives of Virology 164 (11):2799-2804.

\section{Publisher's Note}

Springer Nature remains neutral with regard to jurisdictional claims in published maps and institutional affiliations.

Ready to submit your research? Choose BMC and benefit from:

- fast, convenient online submission

- thorough peer review by experienced researchers in your field

- rapid publication on acceptance

- support for research data, including large and complex data types

- gold Open Access which fosters wider collaboration and increased citations

- maximum visibility for your research: over $100 \mathrm{M}$ website views per year

At $\mathrm{BMC}$, research is always in progress.

Learn more biomedcentral.com/submissions 